\title{
A 10-year study of specimens submitted to oral pathology laboratory analysis: lesion occurrence and demographic features
}

Marina Mendez ${ }^{(a)}$

Vinicius Coelho Carrard ${ }^{(a)}$

Alex Nogueira Haas ${ }^{(b)}$

Isabel da Silva Lauxen ${ }^{(a)}$

João Jorge Diniz Barbachan ${ }^{(a)}$

Pantelis Varvaki Rados ${ }^{(a)}$

Manoel Sant'Ana Filho(a)

(a) Oral Pathology Department, School of Dentistry, Universidade Federal do Rio Grande do Sul (UFRGS), Porto Alegre, RS, Brazil.

(b) Periodontology Department, School of Dentistry, Universidade Federal do Rio Grande do Sul (UFRGS), Porto Alegre, RS, Brazil.

Declaration of Interests: The authors certify that they have no commercial or associative interest that represents a conflict of interest in connection with the manuscript.

Corresponding Author:

Manoel Sant'Ana Filho

E-mail:manoel@ufrgs.br

Received for publication on Sep 02, 2011 Accepted for publication on Feb 15, 2012
Abstract: The purpose of the present paper was to describe the range of lesions histologically diagnosed in an oral pathology laboratory in southern Brazil. A retrospective study of 8,168 specimen analyses recorded between 1995 and 2004 was conducted. The records were retrieved from the Oral Pathology Laboratory, School of Dentistry, Federal University of Rio Grande do Sul, RS, Brazil. A total of 6,831 valid cases $(83.63 \%)$ were examined. Of these, inflammatory lesions were the most common occurrences $(n=4,320 ; 63.24 \%)$. Benign and malignant tumors accounted for $7.66 \%(n=523)$ and $1.9 \%(n=130)$ of the occurrences, respectively. Significant associations were observed between nonneoplastic proliferative disorders and benign mesenchymal tumors in females, and between squamous cell carcinoma and leukoplakia in males. Most diagnoses were benign in nature and had an inflammatory etiology. The association of some demographic characteristics with the occurrence of lesions suggests that these characteristics should be considered in performing differential diagnoses.

Descriptors: Pathology, Oral; Risk; Epidemiology; Retrospective Study.

\section{Introduction}

Biopsy and histopathological analysis are important complementary diagnostic tools that are strongly influenced by clinical data. ${ }^{1}$ The literature is vast regarding estimated occurrences of oral lesions such as oral cancer, ${ }^{2-4}$ as well as odontogenic ${ }^{5,6}$ and salivary gland tumors. ${ }^{7-10}$ Contrarily, only few studies have documented the frequency of histologically confirmed lesions in adults, ${ }^{11-14}$ and data are particularly scarce in Brazil. For instance, Simões et al. ${ }^{15}$ and Nascimento et al. ${ }^{16}$ evaluated 1,040 and 2,147 specimens, respectively, in studies conducted in oral pathology laboratories located in northeastern Brazil. Volkweis et al. ${ }^{17}$ reported 435 cases from a hospital dental clinic in southern Brazil.

Some oral lesions may exhibit similar clinical features, thus rendering the diagnosis more challenging. For instance, the differential diagnosis between nonneoplastic proliferative disorders (NNPD) and benign mesenchymal tumors, and between leukoplakia and squamous cell carcinoma, often poses challenging situations, requiring prior knowledge of demographic characteristics associated with the occurrence of lesions in order to establish a clinical differential diagnosis.

This study aimed at describing the occurrence of oral lesions diagnosed from specimens submitted to oral pathology laboratory analysis in southern 
Brazil over a 10-year period, and to assess demographic characteristics associated with oral lesions exhibiting similar clinical features.

\section{Methodology}

Study design and sample

This study retrospectively analyzed oral pathology archives from the School of Dentistry at the Federal University of Rio Grande do Sul (UFRGS), Porto Alegre, southern Brazil. Every year, about 800 specimens are submitted by private and public health dental practitioners, and mostly by undergraduate students of the institution, for histopathological examination. In addition, the laboratory receives specimens obtained for research purposes from experimental studies. Data from 8,168 specimens recorded between 1995 and 2004 were retrieved from the laboratory files and entered into a dataset by a single researcher.

The study excluded $688(8.42 \%)$ research material specimens of the 8,168 recorded in the laboratory files. In addition, 649 specimens (7.95\%) from descriptive reports were also excluded from the analysis, on the grounds that the amount of tissue was inadequate for diagnosis. Of a total of 6,831 human specimens, age was specified in $92.5 \%$ of cases, and gender was specified in 6,797 cases $(99.5 \%), 62.16 \%(n=4,248)$ of which were females. Data on skin color were available in 6,148 records $(90 \%)$, and showed that 5,304 individuals (77.64\%) were white.

\section{Ethical considerations}

The study was approved by the Research Ethics Committee, School of Dentistry, UFRGS, Brazil (protocol no. 269/08).

\section{Classification criteria}

Lesions were divided into inflammatory lesions, benign tumors, malignant tumors, and others, using clinical diagnosis together with histological findings obtained from the records.

The group of inflammatory lesions was subdivided into the following categories:

- immunologically mediated lesions, corresponding to lichen planus and pemphigus vulgaris;

- NNPD, including reactional lesions induced by traumatic, chemical, or biological agents, such as inflammatory fibrous hyperplasia, pyogenic granuloma, and peripheral giant cell granuloma;

- periapical inflammatory lesions, corresponding to inflammatory tissue damage induced by a necrotic pulp removed after tooth extraction or apical surgery; and

- others.

Benign tumors were subdivided into mesenchymal, odontogenic, epithelial (lining and glandular), osseous, and nervous tumors. Malignant tumors were subdivided into epithelial (lining and glandular) and mesenchymal tumors. Other diagnoses included:

- normal tissue, corresponding basically to dental follicle;

- potentially malignant disorders, including epithelial morphologic changes (leukoplakia) and actinic cheilitis;

- cysts, including odontogenic, non-odontogenic, and unspecified cysts (inflammatory cysts were classified as inflammatory lesions);

- bone-pathology-related, including peripheral ossifying fibroma, periapical cemental dysplasia, and traumatic bone cyst.

\section{Statistical analysis}

Data analysis was performed using the Statistical Package for the Social Sciences (SPSS), version 16 for Macintosh (SPSS Inc., Chicago, USA). The individual was used as a unit of analysis and the significance level was set at $5 \%$. Individuals were divided into two age groups, using 50 years of age as the cutoff point, and classified as whites or nonwhites, according to self-reported skin color information made available in the records. Occurrence of oral lesions was expressed as an absolute value and percentage per diagnostic category.

Two challenging clinical situations involving differential diagnosis were selected and analyzed separately in order to investigate a possible association between demographic characteristics and oral lesions, as follows:

1. Two groups of oral lesions clinically presenting as exophytic-growing soft tissue nodules comprised of mesenchymal tissue were compared. Demographic characteristics for NNPD were determined using benign mesenchymal tumors (including fibroma, lipoma, hemangioma, lymphangioma, xanthoma, and 
spindle cell lesions) as a comparison group.

2. Squamous cell carcinoma and leukoplakia were compared. Demographic risk indicators for squamous cell carcinoma were determined using leukoplakia as a comparison group.

The distribution of subjects with and without a condition, according to gender, age, and skin color was compared using Fisher's exact test. Univariate and multivariate logistic regression models were used to evaluate the association between oral lesions and gender, age, and skin color. Odds ratios (OR) and $95 \%$ confidence intervals $(95 \% \mathrm{CI})$ were reported. Cases with missing data were excluded from the models.

\section{Results}

Tables 1 and 2 show the occurrence of oral lesions according to diagnostic category and histopathological report, respectively. Inflammatory lesions were the most common occurrences, diagnosed in 4,320 cases (63.24\%). Periapical inflammatory lesions were the most common lesions in the inflammatory group. The second most common lesions were NNPD. In the benign tumor category, mesenchymal tumors (benign mesenchymal tumors) were the most frequently diagnosed. Malignant tumors were observed in $1.9 \%$ of cases. Potentially malignant disorders accounted for $2.46 \%$ of total cases. The frequency of other histopathological reports is shown in Table 2.
Table 1 - Occurrence of oral lesions according to diagnostic category.

\begin{tabular}{|c|c|c|c|}
\hline Diagnostic category & Total cases & $\%$ of group & $\%$ of total \\
\hline Inflammatory lesions & 4,320 & 100 & 63.24 \\
\hline Periapical inflammatory lesions & 1,932 & 44.72 & 28.28 \\
\hline Nonneoplastic proliferative disorder (NNPD) & 934 & 21.62 & 13.67 \\
\hline Immunologically mediated lesions & 59 & 1.37 & 0.86 \\
\hline Other inflammatory lesions & 1,395 & 32.29 & 20.42 \\
\hline Benign tumors & 523 & 100 & 7.66 \\
\hline Mesenchymal & 286 & 54.64 & 4.19 \\
\hline Odontogenic & 120 & 22.94 & 1.76 \\
\hline Epithelial (lining) & 91 & 17.39 & 1.33 \\
\hline Epithelial (glandular) & 14 & 2.67 & 0.20 \\
\hline Osseous & 7 & 1.34 & 0.10 \\
\hline Nervous & 5 & 0.96 & 0.07 \\
\hline Malignant tumors & 130 & 100 & 1.90 \\
\hline Epithelial (lining) & 114 & 87.69 & 1.67 \\
\hline Mesenchymal & 10 & 7.69 & 0.15 \\
\hline Epithelial (glandular) & 6 & 4.61 & 0.09 \\
\hline Other diagnoses & 1,858 & 100 & 27.20 \\
\hline Normal tissue & 1,507 & 81.11 & 22.06 \\
\hline Potentially malignant disorders & 168 & 9.04 & 2.46 \\
\hline Cysts & 146 & 7.86 & 2.14 \\
\hline Bone-pathology-related & 37 & 1.99 & 0.54 \\
\hline Total & 6,831 & & 100 \\
\hline
\end{tabular}


No significant differences were observed in the distribution of NNPD and benign mesenchymal tumors according to age and skin color (Table 3). The percentage of female patients with NNPD was significantly higher than that of those with benign mesenchymal tumors $(\mathrm{p}=0.02)$. No multivariate analysis was performed to assess the association between NNPD and benign mesenchymal tumors with demographic characteristics, be-

Table 2 - Most common diagnoses (per diagnostic category) according to histopathological report.

\begin{tabular}{|c|c|c|c|}
\hline Diagnoses & Total cases & $\%$ of group & $\%$ of total \\
\hline Inflammatory lesions & 4,320 & 100 & 63.24 \\
\hline Periapical inflammatory lesion & 1,932 & 44.72 & 28.28 \\
\hline Inflammatory hyperplasia & 719 & 16.64 & 10.53 \\
\hline Mucocele & 185 & 4.28 & 2.71 \\
\hline Pyogenic granuloma & 166 & 3.84 & 2.43 \\
\hline Pericoronitis & 108 & 2.50 & 1.58 \\
\hline Giant cell lesion & 49 & 1.13 & 0.72 \\
\hline Lichen Planus & 28 & 0.65 & 0.41 \\
\hline Benign tumors & 523 & 100 & 7.66 \\
\hline Fibroma & 216 & 41.30 & 3.16 \\
\hline Papilloma & 76 & 14.53 & 1.11 \\
\hline Keratocystic odontogenic tumor & 38 & 7.27 & 0.56 \\
\hline Hemangioma & 34 & 6.5 & 0.50 \\
\hline Odontoma & 30 & 5.74 & 0.44 \\
\hline Malignant tumors & 130 & 100 & 1.90 \\
\hline Squamous cell carcinoma & 113 & 86.92 & 1.65 \\
\hline Undifferentiated malignant neoplasms & 8 & 6.15 & 0.12 \\
\hline Mucoepidermoid carcinoma & 4 & 3.08 & 0.06 \\
\hline Plasmacytoma & 1 & 0.77 & 0.01 \\
\hline Lymphoma & 1 & 0.77 & 0.01 \\
\hline Adenocarcinoma & 1 & 0.77 & 0.01 \\
\hline Adenoid cystic carcinoma & 1 & 0.77 & 0.01 \\
\hline Basal cell carcinoma & 1 & 0.77 & 0.01 \\
\hline Normal tissue & 1,507 & 100 & 22.06 \\
\hline Dental follicle & 1,425 & 94.56 & 20.86 \\
\hline Potentially malignant disorders & 168 & 100 & 2.46 \\
\hline Epithelial morphological changes (leukoplakia) & 152 & 90.48 & 2.23 \\
\hline Actinic cheilitis & 16 & 9.52 & 0.23 \\
\hline Cysts & 146 & 100 & 2.14 \\
\hline Odontogenic & 122 & 83.56 & 1.79 \\
\hline Unspecified & 16 & 10.96 & 0.23 \\
\hline Nonodontogenic & 8 & 5.48 & 0.12 \\
\hline Bone-pathology-related & 37 & 100 & 0.54 \\
\hline Peripheral ossifying fibroma & 15 & 40.54 & 0.22 \\
\hline Benign fibro-osseous lesion & 11 & 29.73 & 0.16 \\
\hline Traumatic bone cyst & 9 & 24.32 & 0.13 \\
\hline Periapical cemental dysplasia & 2 & 5.41 & 0.03 \\
\hline
\end{tabular}


Table 3 - Distribution of subjects with exophytic-growing oral nodules (nonneoplastic proliferative disorder and benign mesenchymal tumors),

leukoplakia and squamous cell carcinoma according to demographic characteristics

\begin{tabular}{|c|c|c|c|c|c|c|}
\hline \multirow[t]{2}{*}{$\begin{array}{l}\text { Demographic } \\
\text { characteristic }\end{array}$} & \multirow{2}{*}{$\begin{array}{c}\text { Nonneoplastic } \\
\text { proliferative } \\
\text { disorder }\end{array}$} & \multirow{2}{*}{$\begin{array}{c}\text { Benign } \\
\begin{array}{c}\text { mesenchymal } \\
\text { tumor }\end{array} \\
\mathrm{n}(\%)\end{array}$} & \multirow[t]{2}{*}{$\mathrm{p}^{*}$} & Leukoplakia & $\begin{array}{l}\text { Squamous cell } \\
\text { carcinoma }\end{array}$ & \multirow[t]{2}{*}{$\mathrm{p}^{*}$} \\
\hline & & & & $\mathrm{n}(\%)$ & n $(\%)$ & \\
\hline \multicolumn{7}{|c|}{ Age } \\
\hline $30-49$ years & $116 \quad(15.5)$ & $29 \quad(13.2)$ & & $20 \quad(14.6)$ & $(6.0)$ & \\
\hline$\geq 50$ years & $632 \quad(84.5)$ & $191 \quad(86.8)$ & 0.45 & $117 \quad(85.4)$ & $94 \quad(94.0)$ & 0.06 \\
\hline \multicolumn{7}{|c|}{ Gender } \\
\hline Male & $184 \quad(24.6)$ & $73 \quad(33.2)$ & & $70 \quad(51.1)$ & $(72.0)$ & \\
\hline Female & $564 \quad(75.4)$ & $147 \quad(66.8)$ & 0.02 & $67 \quad(48.9)$ & $(28.0)$ & 0.001 \\
\hline \multicolumn{7}{|c|}{ Skin color } \\
\hline White & $652 \quad(87.2)$ & $194 \quad(88.2)$ & & $123 \quad(89.8)$ & $88 \quad(88.0)$ & \\
\hline Nonwhite & $96 \quad(12.8)$ & $26 \quad(11.8)$ & 0.73 & $14 \quad(10.2)$ & $12 \quad(12.0)$ & 0.68 \\
\hline Total & $748(100.0)$ & $220(100.0)$ & & $137(100.0)$ & $100(100.0)$ & \\
\hline
\end{tabular}

* Fisher's exact test.
Table 4 - Univariate logistic regression analysis of the association between nonneoplastic proliferative disorder and demographic characteristics (benign mesenchymal tumor as a comparison group).

\begin{tabular}{l|c|c}
\hline Demographic characteristic & OR $(95 \% \mathrm{CI})$ & $\mathrm{p}$ \\
\hline $30-49$ years & 1 & \\
\hline$\geq 50$ years & $1.21(0.78-1.87)$ & 0.40 \\
\hline \multicolumn{3}{|c}{ Gender } \\
\hline Male & 1 & 0.01 \\
\hline Female & $1.52(1.10-2.11)$ & \\
\hline \multicolumn{3}{|c}{ Skin color } \\
\hline White & 1 & 0.69 \\
\hline Nonwhite & $0.91(0.57-1.45)$ & \\
\hline
\end{tabular}

$\mathrm{CI}=$ confidence interval; $\mathrm{OR}=$ odds ratio

cause only gender was found to be significantly associated with the occurrence of NNPD $(\mathrm{OR}=1.52, \mathrm{p}=0.01$; Table 4).

The percentage of females with squamous cell carcinoma (28\%) was lower than that of those with leukoplakia $(48.9 \%)(p=0.001$, Table 3$)$. There were no significant differences in the distribution of carcinoma and leukoplakia, according to age and skin color. In the multivariable logistic regression model (Table 5), significant associations were observed for age and gender. Females had a $61 \%$ lower chance of developing squamous cell carcinoma than males $(\mathrm{p}=0.001)$. Patients over 50 years
Table 5 - Logistic regression analysis of the association between squamous cell carcinoma and demographic characteristics (leukoplakia as a comparison group).

\begin{tabular}{l|c|c}
\hline $\begin{array}{l}\text { Demographic characteristic } \\
\text { Adjusted estimates }\end{array}$ & OR $(95 \% \mathrm{CI})$ \\
\hline \multicolumn{3}{|c}{ Age } \\
\hline $30-49$ years & 1 & 0.03 \\
\hline$\geq 50$ years & $2.95(1.12-7.79)$ & \\
\hline \multicolumn{3}{|c}{ Gender } \\
\hline Male & 1 & 0.001 \\
\hline Female & $0.39(0.22-0.68)$ & \\
\hline
\end{tabular}

$\mathrm{CI}=$ confidence interval; $\mathrm{OR}=$ odds ratio.

of age were 2.68 times more likely to have squamous cell carcinoma than younger individuals $(\mathrm{p}=0.03)$.

\section{Discussion}

The present study demonstrated that the overall distribution of lesions analysed in a Brazilian oral pathology laboratory was similar to that observed in other laboratories in the United Kingdom, ${ }^{11}$ United States of America ${ }^{12-14}$ and Brazil. ${ }^{15-17}$ Most specimens analyzed in this reference oral pathology laboratory were diagnosed over a 10 -year period as inflammatory lesions or normal tissue. Benign and malignant tumors were found in only $7.66 \%$ and $1.9 \%$ of specimens, respectively.

The majority of specimens analyzed corresponded to inflammatory lesions, corroborating data from pre- 
vious studies. ${ }^{11-17}$ Periapical inflammatory lesions and NNPD were the most frequent lesions in this diagnostic category. The frequency of periapical inflammatory lesions was similar to that reported by Jones and Frank$\operatorname{lin}^{11}$ and Baskar, ${ }^{14}$ but much higher than that described by Weir et al. ${ }^{12}$ Simões et al. ${ }^{15}$ Nascimento et al. ${ }^{16}$ and Volkweis et al. ${ }^{17}$ This finding may be related to the profile of our sample, in which most patients sought tooth extraction as a treatment for decayed teeth usually associated with periapical inflammatory lesions. Moreover, it is important to emphasize that specimen sources vary considerably among oral pathology laboratories. Weir et al. ${ }^{12}$ reported that $80 \%$ of their sample was obtained from a private office, which could affect the pattern of lesion occurrence. Unfortunately, comparisons with other studies are difficult, because this information is usually not provided..$^{11,15,16}$

Inflammatory hyperplasia was the major entity found among NNPD cases, which is consistent with data from other studies. ${ }^{11,13,16}$ The slightly higher prevalence of this pathological condition may be explained in part by the high prevalence of edentulous individuals in Brazil, ${ }^{18}$ who tend to use the same prosthesis over decades or resort to low-cost prosthetic rehabilitation ${ }^{19}$ under inappropriate conditions because of their low socioeconomic status.

Females had a higher occurrence of NNPD and benign mesenchymal tumors than males. These data may reflect the fact that women seek oral health services more often than men, in accordance with epidemiological studies reporting that males generally have a poorer health status than females. ${ }^{20}$ Women were also more likely to have NNPD than men, when compared to benign mesenchymal tumors, a finding that may be attributed to a high frequency of prosthesis use among women, as demonstrated in a previous study conducted in the same geographic region. ${ }^{19}$

Fibroma was the most frequent diagnosis in the benign tumor group, supporting previous findings reported in the literature. ${ }^{12,15}$ In contrast, Jones and Franklin ${ }^{11}$ reported a high occurrence of squamous papillomas and a low proportion of fibromas. ${ }^{11}$ These contradictory findings may be attributed to differences in the immunological profile of the populations, since squamous papillomas are associated to human papillomavirus, ${ }^{21}$ and also to the histopathological criteria used for oral fibroma. ${ }^{22}$

Malignant tumors accounted for $1.9 \%$ of specimens, which is in accordance with previous reports. ${ }^{12,13,16}$ Men older than 50 years of age were more closely associated with squamous cell carcinoma when leukoplakia was used as a reference group, reinforcing associations observed in previous studies. ${ }^{13}$ This association is probably an effect of long-term exposure to risk factors such as tobacco and alcohol. Although men were more likely to have squamous cell carcinoma than women, it has been demonstrated that the male-female ratio disparity has decreased over the past years, probably because of a change in women's behavior in relation to smoking and alcohol consumption. ${ }^{23,24}$

It has been demonstrated that some factors, such as age, gender, socioeconomic status, prosthesis use, smoking and alcohol consumption, may be associated to oral lesions. ${ }^{19}$ Unfortunately, these data are frequently not informed by surgeons when histopathological evaluation is requested. The associations related to gender and age observed in the present study could be explained by the cumulative effects of smoking and alcohol consumption. Since information regarding behavioral factors was not available in the files of the Laboratory, we were unable to evaluate these factors in the present study.

\section{Conclusion}

In conclusion, most diagnoses were benign in nature and had an inflammatory etiology. Age and gender may be considered demographic characteristics to be used for the differential diagnosis of major oral lesions.

\section{Acknowledgements}

The authors would like to thank Mr. Leandro Nunes, Dr. Rafael Shöller and Dr. Germano Freitas for their support with data management, and also Dr. Ana Luisa H. de Carvalho and Dr. Fernando N. Hugo for their critical review. This study was partially funded by PIBIC/ CNPq.

\section{References}

1. Mota-Ramírez A, Silvestre FJ, Simó JM. Oral biopsy in dental practice. Med Oral Patol Oral Cir Bucal. 2007 Nov 1;12(7):504-10.

2. dos Santos LCO, Cangussu MCT, Batista OM, dos Santos JP. Oral Cancer: population sample of the state of Alagoas at a Reference Hospital. Braz J Otorhinolaryngol. 2009 Jul-Aug;75(4):524-9. 
3. Losi-Guembarovski R, Menezes RP, Poliseli F, Chaves VN, Kuasne $\mathrm{H}$, Leichsenring A, et al. Oral Carcinoma Epidemiology in Paraná State, Southern Brazil. Cad Saude Publica. 2009 Feb;25(2):393400.

4. Borges FT, Garbin CAS, Carvalhosa AA, Casto PHS, Hidalgo LRC. [Oral cancer epidemiology in a public laboratory in Mato Grosso State, Brazil]. Cad Saude Publica. 2008 Sep;24(9):1977-82. Portuguese.

8. de Oliveira FA, Duarte ECB, Taveira CT, Maximo AA, de Aquino EC, Alencar RC, et al. Salivary gland tumor: a review of 599 cases in a Brazilian population. Head Neck Pathol. 2009 Dec;3(4):271-5.

9. Ito SA, Ito K, Vargas PA, de Alemida OP, Lopes MA. Salivary gland tumors in a Brazilian population: a retrospective study of 496 cases. Int J Oral Maxillofac Surg. 2005 Jul;34(5):533-6.

10. Lima GS, Fontes ST, Araújo LMA, Etges A, Tarquinio SBC, Gomes APN. A survey of oral and maxillofacial biopsies in children. A single- center retrospective study of 20 years in Pelotas-Brazil. J Appl Oral Sci. 2008 Nov-Dec;16(6):397-402.

11. Jones AV, Franklin CD. An analysis of oral and maxillofacial pathology found in adults over a 30-year period. J Oral Pathol Med. 2006 Aug;35(7):392-401.

12. Weir JC, Davenport WD, Skinner RL. A diagnostic survey of 15,783 oral lesions. J Am Dent Assoc. 1987 Sep;115(3):439-41.

13. Rossi EP, Hirsch SA. A survey of 4,793 oral lesions with emphasis on neoplasia and premalignancy. J Am Dent Assoc. 1977 May;94(5):883-6.

14. Bhaskar NS. Oral pathology in the dental office: survey of 20,575 biopsy specimens. J Am Dent Assoc. 1968 Apr;76(4):761-6.

15. Simões CA, Lins RC, Henriques ACG, Cazal C, Castro JFL. [Prevalence of lesions diagnosed in maxillofacial region in oral pathology laboratory Federal University of Pernambuco]. Int J Dent. 2007 Apr-Jun;6(2):35-8. Portuguese.

16. Nascimento GJF, Paraiso DP, Goes PSA, Sobral APV. [Epidemiological study of 2.147 cases of oral and maxillofacial lesions]. Rev Bras Patol Oral. 2005;4(2):82-9. Portuguese.

17. Volkweis MR, Garcia R, Pacheco CA. [Retrospective study of oral lesions in the population attended at the Dental Specialty Center]. RGO. 2010 Jan-Mar;58(1):21-5. Portuguese.

18. Ministério da Saúde (BR). Projeto SB Brasil: condições de saúde bucal da população brasileira 2002-2003 - resultados principais. Brasília (DF): Ministério da Saúde; 2004 [citado 20 maio 2011]. 52 p. Disponível em: http://www.apcd.org.br/anexos/projetos_sociais/ projeto_sb.pdf.

19. Carrard VC, Haas AN, Rados PV, Filho MS, Opperman RV, Albandar JM, et al. Prevalence and risk indicators of oral mucosal lesions in an urban population from South Brazil. Oral Dis. 2011 Mar;17(2):171-9.

20. Instituto Brasileiro de Geografia e Estatítica (BR). Indicadores Sociodemográficos e de Saúde no Brasil. Rio de Janeiro: IBGE; 2009. [citado 20 maio 2011]. 152 p. Disponível em http://www.ibge.gov.
5. Fernandes AM, Duarte ECB, Pimenta FJGS, Souza LN, Santos VR, Mesquita RA, et al. Odontogenic tumors: a study of 340 cases in a Brazilian population. J Oral Pathol Med. 2005;34(10):583-7.

6. Avelar RL, Antunes AA, Carvalho RWF, Bezerra PGCF, Oliveira Neto PJ, Andrade ESS. Odontogenic cysts: a clinicopathological study of 507 cases. J Oral Sci. 2009;51(4):581-6.

7. Lima SS, Soares AF, Amorim RFB, Freitas RA. [Epidemiologic profile of salivary gland neoplasms: analysis of 254 cases]. Rev Bras Otorrinolaringol. 2005 May-Jun;71(3):335-40. Portuguese.

br/home/estatistica/populacao/indic_sociosaude/2009/indicsaude. pdf.

21. Syrjänen S. Human Papillomavirus infections and oral tumors. Med Microbiol Immunol. 2003 Aug;192(3);123-8.

22. Cristopoulos P, Sklavounou A, Patrikiou A. True fibroma of the oral mucosa. A case report. Int. J. Oral Maxillofac. Surg. 1994 Apr;23(2):98-99.

23. Neville BW, Day TA. Oral cancer and precancerous lesions. CA Cancer J Clin. 2002 Aug;52(4):195-215.

24. Kruse AL, Bredell M, Grätz KW. Oral cancer in men and women: are there differences?. Oral Maxillofac Surg. 2011 Mar;15(1):51-5. 